\title{
APONTAMENTOS SOBRE A NARRATIVIDADE E A ASPECTUALIZAÇÃO DO ATO DE JOGAR NO JOGO SUPER MARIO WORLD
}

\author{
NARRATIVITY AND ASPECTUALIZATION ON PLAYING SUPER MARIO WORLD
}

\author{
Mário Sérgio Teodoro da Silva Junior \\ Universidade Estadual Paulista "Júlio de Mesquita Filho", Brasil \\ junior.marioteodoro@gmail.com
}

\begin{abstract}
RESUMO: Este artigo destina-se a identificar as marcações no enunciado do jogo de videogame Super Mario World, de 1990, que permitam enxergar o fluxo da ação de controle operada pelo jogador visado pela enunciação. Para tanto, deve-se estabelecer a distinção entre a instância enunciada do enunciatário, o narratário, a quem o narrador instrui e comanda, e a instância do enunciado enunciado, em que se localiza o herói Mario, aquele comandado pelo narratário. As categorias narrativas e discursivas ora são comuns, ora diversas para esses sujeitos, estruturando graus de sincretismo de suas identidades e de seus percursos. É no percurso do narratário em que são encontradas as dinâmicas sensíveis que demarcam o ritmo do processo de jogo, o tempo necessário para se tornar hábil e vencer.
\end{abstract}

PALAVRAS-CHAVE: semiótica; videogames; narratividade.

ABSTRACT: In this article, our goal is to identify the syntax of control which a video game player plays, in the game Super Mario World, from Nintendo (1990), basing our notes on the many marks left in the audiovisual text, in the form of figures and narrative programs. Therefore, two levels must be distinguished: one concerning the player, referred in the text as a naratee, and another concerning the enounced hero, Mario. The discursive categories and narrative patterns are sometimes the same and sometimes different for each actor, proposing syncretism degrees for their identities and their syntaxes. It is in the course of the naratee that the sensitive dynamics that mark the rhythm of the game process are found, besides the time needed to become skilled and to win.

KEYWORDS: semiotics; video games; narrativity.

\section{Introdução}

Em publicação recente, Jacques Fontanille reviu a posição da semiótica entre as ciências humanas do século XXI e suas contribuições para a vida social. Ele cita o meio ambiente, a sustentabilidade, a manutenção do patrimônio cultural, o empreendedorismo, a segurança pública e a saúde como possíveis campos de averiguação do sentido das estruturas das práticas e das formas de vida. São esses campos com os quais a semiótica contribui estudando textos, objetos, atos e instituições, por "sua capacidade de transformar a médio e longo prazos a nossa relação com nós mesmos, com a sociedade, com a vida e com a natureza." (FONTANILLE, 2016a, p. 1).

Assim, em direção ao desenvolvimento da semiótica no campo da enunciação em 
ato e das identidades sociais, reservarmo-nos ao estudo da integração dos textos às práticas semióticas, ressaltando as qualidades sensoriais aí envolvidas e seu papel na significação. Os games são uma mídia sobre a qual qualquer estudo pode tanto contribuir com aplicações imediatas nos perfis mercadológicos quanto abrir um dos caminhos possíveis de compreensão do perfil interacional e ético da atual e da futura geração (Cf. CALLIARI; MORRA, 2012), por serem práticas que permitem aos seus usuários interagirem entre si, compartilharem suas conquistas do jogo online, policiarem seu próprio agir e se inserirem em um ciclo de mercado que está sempre a lançar novos títulos, consoles e controles, aprimorando constantemente sua tecnologia.

Trabalhos nessa direção já ocorrem, mas com enfoques diferentes do que pretendemos aqui, reservando-se à semionarratividade, à interação na Comunicação, à aplicação didática ou a consequências à saúde (Cf. ANGELO, 2015, ERNICA, 2014, OLIVEIRA; MARINHO, 2010 e SOUZA JÚNIOR, 2009, 2015). O que visamos neste projeto é compreender o contato sensorial entre o jogador o videogame e como o sentido gerado a partir daí integra-se nos níveis de textos, de objetos e de cenas predicativas.

Neste artigo, o ponto específico que iremos abordar é o desenvolvimento da ação de operação do jogo, o tempo e qualidade que o jogador investe nos diversos momentos da sintaxe, mas observados em sua prefiguração textual, isto é, na maneira como também a ação do herói enunciado do videogame consegue determinar coerções sobre o andamento do ato de jogar.

\section{Material e método}

Como material de análise, elegemos o jogo Super Mario World, de 1990, desenvolvido pela Nintendo para o Super Nintendo Entertainment (SuperNES), ou Super Nintendo, como também é conhecido. Trata-se do quarto título de uma franquia envolvendo o protagonista Mario e outras personagens regulares. O primeiro jogo foi Super Mario Bros, de 1985, para o console antecessor do SuperNES (ver Figura 1).
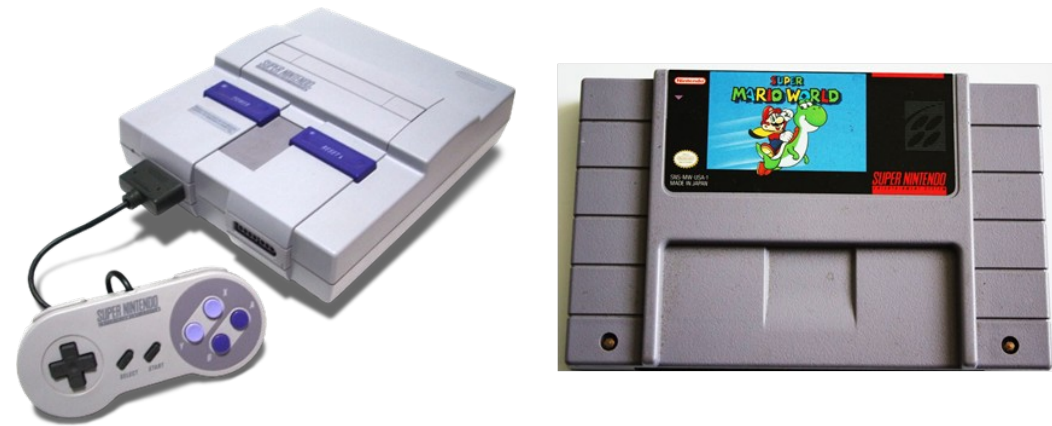

Figura 1: à esquerda, o console Super Nintendo e, à direita, o cartucho de Super Mario World. Fonte: Super Mario Wiki. Disponível em: https://www.mariowiki.com/. Acesso em: 18 jan. 2019.

No jogo, Mario faz parte de um mundo habitado por vegetais e animais falantes, em que a missão do herói, assim como em outros títulos da franquia, é resgatar a princesa Toadstool (cogumelo), governante do Reino dos cogumelos, do vilão Bowser, rei dos Koopa, uma raça de tartarugas (ver Anexos). A fantasia e a política emaranham-se em 
uma jornada que consiste, via de regra, na exploração de terras desconhecidas, no descobrimento de novas espécies e no reconhecimento da lógica funcional desse outro mundo. Constitui-se um percurso que vai de conhecer as coisas e regimes desse lugar de fantasia a cumprir as determinações narrativas e a tornar-se o salvador do dia.

Concomitante a esse enunciado relativo ao ator Mario e à sua jornada, há um fazer persuasivo entre enunciador e enunciatário. Nessa relação actorial residem as questões corporais, narrativas e aspectuais que permitem enxergar o trânsito do jogador pelo jogo. Assim, a análise do percurso narrativo de Mario, levando em conta as categorias discursivas que lhe dão concretude, levará à análise e às considerações sobre o percurso narrativo do jogador de Super Mario World (SMW) e a modulação do andamento do ato de jogar.

Por se tratar de um jogo com considerável extensão temporal, recortamos apenas a jogada da primeira área que o herói explora, os primeiros níveis, até o primeiro "chefe", o primeiro grande oponente, que ele derrota. É possível conferir esse primeiro momento do jogo em diversas gravações disponíveis online ${ }^{1}$. Apesar de observar uma jogada realizada, o objetivo não é identificar o perfil de jogo de um determinado jogador; afinal, o escopo é a interatividade e a fecundidade do ato da leitura do texto em produzir alguns sentidos possíveis para ele. Logo, é preciso enxergar os elementos figurativos e marcos narrativos - as mortes, as falhas, a conquista de objetos modais, as vitórias, etc. - como pequenos sintagmas que podem se alocar ao longo da sintaxe do game, a partir de um conjunto conciso de possibilidades, com coerência em torno do projeto enunciativo.

\section{Posicionamentos teóricos}

A seguir, expõem-se três breves discussões teóricas que direcionam nosso modo de apreender o jogo: primeiramente, há apontamentos acerca do corpo como dimensão interativa no videogame; após, outra seção para tratar da pertinência de trazer a uma área científica dedicada à instância semiótica, que não se ocupa primordialmente dos sujeitos ontológicos, reflexões sobre o uso, que implicam tais sujeitos reais; e, por fim, uma reflexão relativa à técnica de segmentação do conteúdo do enunciado, que acaba por corroborar o modo como o uso interativo se anuncia sob uma forma textual.

São apenas três esboços de discussão, e, ao longo da prática de análise, outros tópicos teóricos e técnicos da literatura semiótica serão suscitados conforme necessidade e pertinência, como as propostas de Landowski acerca dos regimes de interação (LANDOWSKI, 2014).

\subsection{O corpo como competência sensível}

É certo que o termo corpo está sendo usado longe de seu conteúdo na vida real, aquele biologicamente responsável pela sobrevivência e, simbolicamente, motivado e

1 Cf. https://www.youtube.com/watch?v=j8YFxB6rYlo, acesso em: 28 fev. 2019. Os arquivos de gravação própria foram adicionados à submissão como documentos suplementares. 
atravessado pela mais diversa e ampla sorte de valores. Na verdade, essa palavra entra em nossa metalinguagem por influência da literatura semiótica, da qual vale citar o uso de Jacques Fontanille e o de Norma Discini, cujas obras Corps et sens (FONTANILLE, 2016b) e Corpo e estilo (DISCINI, 2015) são determinantes nas configurações contemporâneas de nossa área.

Nessa perspectiva, grosso modo, o corpo é uma dimensão relativa à subjetividade, imbricado na significação por sua capacidade relacional. Na semiose, seu papel relacional é a atribuição de valor ao mundo e o agenciamento de outros corpos em percursos narrativos. No contato intersubjetivo, o corpo tem função de se modificar e de modificar o outro, ao mesmo tempo em que cria para si uma identidade própria e, para o outro, uma identidade mais ou menos díspar.

Para melhorar a precisão terminológica, deve-se entender "corpo do jogador" como "competências corporais do enunciatário". Trata-se do sentir, da competência estésica, conforme aponta Landowski (2014, p. 50). Ela permite ao enunciatário do texto de um videogame cumprir sua ação, junto ao conhecimento adquirido (o saber) e aos poderes acumulados (o poder). A estesia como competência age no âmago da capacidade do sujeito de ser vitorioso ou perdedor, compondo a identidade do jogador.

No reconhecimento da extensão dessa competencialização estésica, é possível circunscrever as diferentes durações delegadas a cada outros estágios de ação do jogador.

\subsection{O sujeito da enunciação e o jogador}

Enunciatário e jogador são termos distintos, mas, por sofrerem sincretismos ao longo da experiência de jogar, é possível, às vezes, permutar suas designações; aquele é discursivo, este, o sujeito cultural, mas não uma pessoa específica, e sim um estereótipo, um protótipo de pessoa. Suas distinções específicas são relativas aos níveis de pertinência em que eles figuram, tendo em mente a proposta de Fontanille sobre as expressões da experiência semiótica (FONTANILLE, 2008a, 2008b).

Se, por um lado, nosso escopo é discursivo, por outro, não se pode negar, justamente por esse escopo, os impactos do discurso sobre o mundo social. É no discurso em que circulam as ideologias, é nele em que o ser humano convence a si mesmo das verdades que dissemina e, a partir dele, encontra forças para fazer a manutenção ou transformar as estruturas sociais.

O modo como um videogame enuncia suas possibilidades sensíveis de interação para seu destinatário é o ponto de ligação do objetivo de minha pesquisa com outras compreensões possíveis em torno desse mesmo objeto. O lugar até onde é possível chegar pela semiótica - a competência sensível do enunciatário - é o lugar de onde propostas mais ligadas à sociedade e ao mercado dos games podem ganhar contribuições para suas próprias compreensões teóricas e técnicas dessa mídia.

Isso ocorre porque o discurso visa a uma pessoa real. Quando um game é utilizado propriamente - adentrando um terreno que não é especificidade das ciências da linguagem, mas das ciências sociais, da publicidade, do design, do desenvolvimento de produtos, etc. - o utilitário irá atualizar a identidade do enunciatário, converter-se em um sujeito igualmente avaliável (premiável ou punível), e gerar consciência e valorações 
sobre aquelas competências de seu corpo. O enunciador, atualizado como a empresa do jogo, será igualmente validado pela amplitude de seu julgamento e na quantidade de atores (sociais) que se sujeitam a ele.

Essa correlação não é livre e sim baseada na compreensão fontanilliana da semiótica discursiva. Ao balizar nosso campo teórico por meio de problemáticas dos fenômenos do sentido na vida social, o autor francês concatena as diferentes experiências materiais e sensíveis que um sujeito estabelece com uma semiótica-objeto, cujo sentido é uma unidade concisa e englobante dos níveis pressupostos e pressuponentes (FONTANILLE, 2008b) (ver Figura 2).

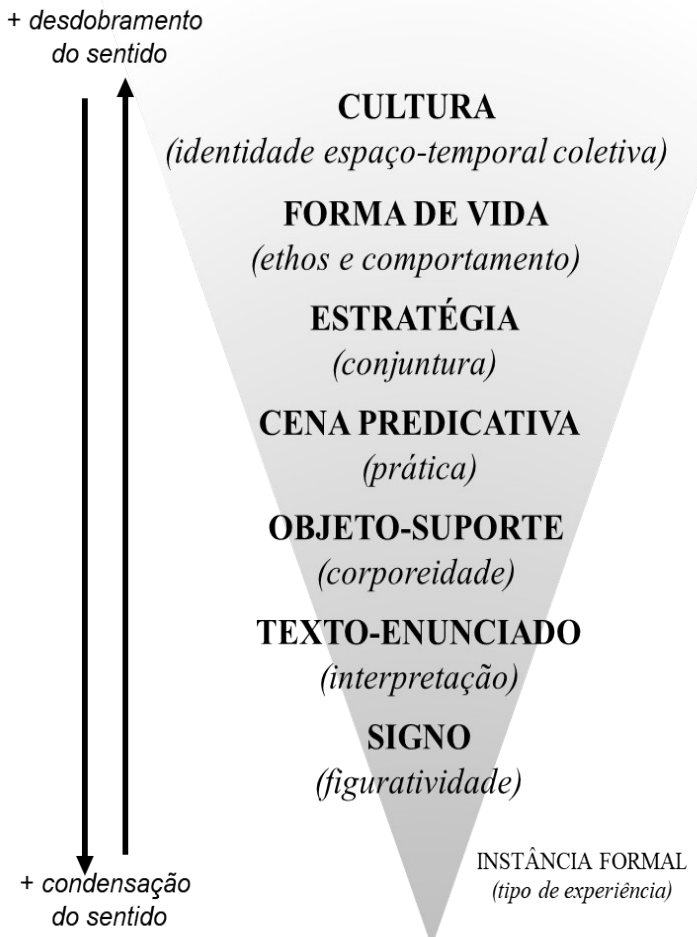

Figura 2: os níveis de expressão da experiência, de Jacques Fontanille.

Fonte: Adaptado de Portela (2008a, p. 110).

Para dar conta da complexidade do videogame como um produto social, é preciso apreendê-lo como um texto-enunciado (o jogo audiovisual), também como um objetosuporte (os aparatos físicos) e como uma cena-predicativa (o processo de jogar), pois eles articulam as materialidades e os sentidos que localizam o corpo do sujeito como vórtice sensível e perceptivo, que interpreta o texto, sente o objeto e conduz a prática. Ainda, é inegável a importância da estratégia resultante do conjunto - a motivação, que revela a volição como competência e o ambiente ideológico na manipulação do sujeito - e da forma de vida que é incorporada ou que se tenta incorporar - a corroboração da ideologia em um ethos reconhecível como comportamento sociohistoricamente marcado.

$\mathrm{Na}$ verdade, pensar em uma semiótica da experiência consiste muito mais em integrar a completude do sentido e torná-la visível à análise que segmentar níveis a serem apreendidos isoladamente. A experiência é uma globalidade que não é tomada parcialmente pelo receptor do discurso, mas em uma toada só. 
Mas esse esboço de tipologia das experiências é por si mesmo enganoso, porque antes de sua declinação em "semióticas-objeto" e em níveis de pertinência, a própria experiência é indivisível e holística e, assim, é a hierarquia dos planos de imanência que induz retroativamente a uma hierarquização e a uma segmentação da experiência (FONTANILLE, 2008b, p. 27).

Nessa direção, toda a extensão da cadeia de expressões da experiência semiótica é apreensível qualquer seja o nível elegido didaticamente para a redação da análise. Logo, estudar o enunciatário de um videogame é estudar a faceta textual de um jogador. Qualquer uso particular parte das mesmas condições discursivas do enunciado a ser analisado aqui.

\subsection{O sujeito da enunciação e o sujeito enunciado}

O enunciatário tem uma faceta implícita, que corresponde mais proximamente a um sujeito culturalmente marcado que a enunciação imagina operando o videogame, mas possui também uma faceta enunciada. Na semiótica standard, distinguem-se quatro instâncias que nivelam implícitos pressupostos e explícitos enunciados:

i. o enunciado, que é a completude do dito e do expresso. É o texto, com seu conteúdo e expressão;

ii. a enunciação, que é a instância pressuposta pelo texto, responsável pelo gesto de inscrição, pela textualização e pela organização do conteúdo. É o ato comunicativo, do qual o texto é componente;

iii. a enunciação enunciada, a parte desse ato comunicativo que se deixa textualizar, que se deixa materializar no texto, dando expressão ao sujeito da enunciação;

iv. e o enunciado enunciado, aquilo que é textual, mas não compete à representação do sujeito da enunciação, senão apenas a, no caso selecionado, Mario, à princesa, a Bowser, etc.

Por isso, quando o destinatário está explicitamente instalado no enunciado (a enunciação enunciada), ele será chamado de narratário - e o mesmo vale para o destinador do discurso, que, enquanto enunciado, nomeia-se de narrador.

Actantes da enunciação enunciada, são eles diretamente delegados do enunciador e do enunciatário, e podem encontrar-se em sincretismo com um dos actantes do enunciado (ou da narração), tal como o sujeito do fazer pragmático ou o sujeito cognitivo [...] (GREIMAS; COURTÉS, 2013, p. 327).

O enunciatário, como sujeito pressuposto à destinação do texto-enunciado, é a interface com a cena predicativa. Dessa maneira, o operador da prática, aquele que realiza a ação de jogar em um mundo real, está prescrito, no texto, como narratário; eles se sincretizam em maior ou menor grau. Por sua vez, o narratário também se confunde, mais ou menos, com a personagem protagonista.

Segmentando esses sujeitos em níveis de pertinência, intratextuais e extratextuais, homologa-se o ato de jogar ao enunciado do jogo, homologa-se o jogador (operador) ao sujeito Mario, com a intermediação da figura do enunciatário em sua forma enunciada, 0 narratário: JOGADOR $\leftrightarrow$ ENUNCIATÁRIO $\leftrightarrow$ NARRATÁRIO $\leftrightarrow$ MARIO. 
Logo, é no desenvolvimento narrativo do narratário e em sua duração que é possível falar em aspecto do ato de jogar, sem de fato de adentrar instâncias ontológicas de um sujeito encarnado, mas mantendo-se em princípios semióticos de um sujeito discursivo. É também no percurso do narratário que se dá a competencialização estésica. Esse percurso dá o ritmo mais próximo da cena predicativa, dá o tempo e a ordem com que se joga. Enquanto o destino da personagem é bastante linear - ela anda sempre em frente na sua história -, o andar do narratário é sinuoso - ele apreende, erra, retorna, treina, tenta novamente, erra, ou acerta, e assim por diante.

\section{0 percurso narrativo de Mario}

Ao iniciar o jogo, após o logotipo da Nintendo, surge uma tela em que se pode optar por continuar uma partida já salva ou iniciar uma nova, e a quantidade de jogadores que irão participar. Até que se pressione qualquer botão no joystick, uma animação se repete, mostrando Mario em plena ação, com o dinossauro Yoshi, derrotando algumas tartarugas koopa. A trilha sonora, por sua vez, é bastante agitada e também é cíclica.

Ao iniciar novo o jogo, Mario aparece em frente a um cenário com grama e terra sendo mostrados na parte inferior da tela, e construções altas, que se assemelham a montanhas meio à bruma, figurando bem ao fundo. A seguinte mensagem surge em um quadrado preto centralizado: "Welcome! This is Dinosaur Land. In this strange land we find that Princess Toadstool is missing again! Looks like Bowser is at it again!"2. Novamente, a trilha começa intensa, mas dessa vez com notas mais longas, fazendo o som se prolongar, como se ele anunciasse o início da jornada, vide também o timbre metálico tal qual se tratasse de trompetes, como os que anunciam a entrada de um importante ator em situações oficiais e formais da realeza (ver Figura 3).

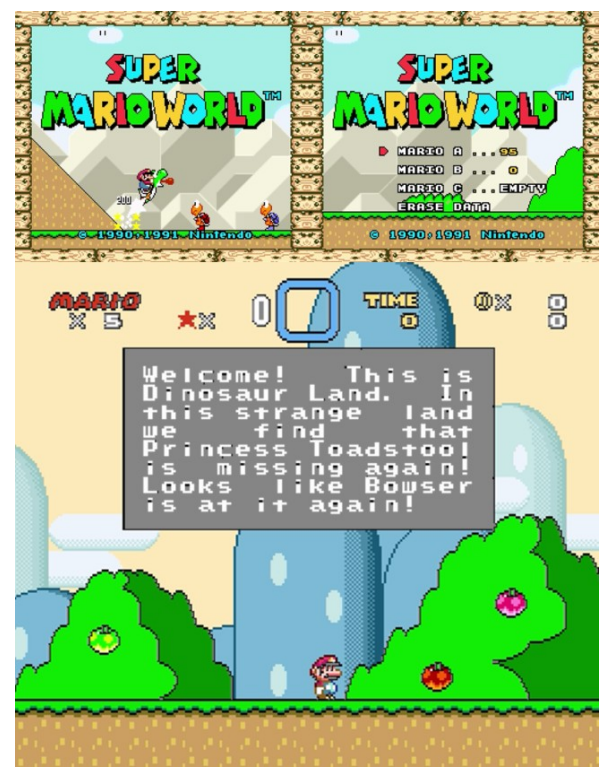

Figura 3: acima, a tela de seleção do jogo. Abaixo, o texto de introdução do novo jogo.

2 Bem-vindo! Essa é a Terra Dinossauro. Nesse país estranho, descobrimos que a Princesa Cogumelo desapareceu de novo! Parece que Bowser está por trás disso novamente! (Tradução nossa). 
Então, a tela sofre um esmaecimento para a cor preta e Mario, miniaturizado, posiciona-se sobre um mapa que possui regiões ligadas por um caminho, uma rota desenhada em cor clara, e regiões e caminhos ainda não ligados, mas com o esboço da rota já feito, em tons mais escuros. Mario fica posicionado, inicialmente, sobre o lugar que se chama Casa do Yoshi (Yoshi's house), como aparece no topo da tela do mapa, onde também se vê outra miniatura do herói e um número disposto logo em frente a ele, a quantidade de Marios, que reflete a quantidade de vidas disponíveis. O som é de flautas e assobios, acelerado e cíclico.

Assim, a casa do Yoshi é o primeiro nível ou fase de SMW, mas, quando Mario a adentra, não há inimigos, não há princesa, não há Bowser, apenas a casa, com uma lareira acesa, pássaros sobre as árvores, que fazem inclusive a vez de telhado da residência, uma caixa de correio, o nome do morador e um alto-falante quadrado, pequeno, logo acima da cabeça de Mario. Quando ele pula, surge um aviso em preto centralizado e grande: "Hello! Sorry I'm not home, but I have gone to rescue my friends who were captured by Bowser. - Yoshi"3. Quando a personagem direciona-se para qualquer dos lados do cenário, ela deixa o nível (ver Figura 4).

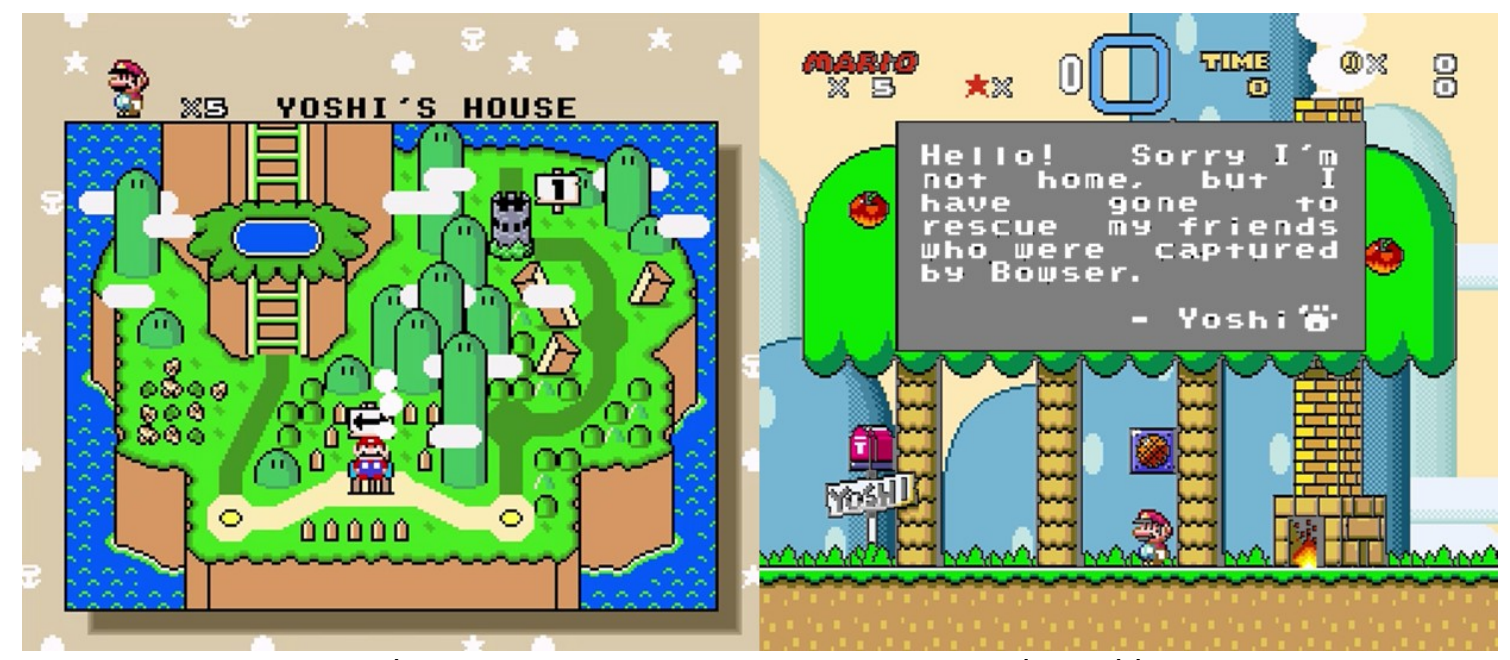

Figura 4: o mapa e a mensagem na casa de Yoshi.

De volta à tela do mapa, o mini-Mario pode mover-se para esquerda ou para direita, e jogar já dois níveis diferentes. À esquerda, está a fase chamada Ilha do Yoshi 1 (Yoshi's Island 1), aquela à direita é a Ilha do Yoshi 2 e assim sucessivamente, até o número 4.

Até esse momento, o tema do resgate está bem colocado no nível discursivo, tal como o tema do exótico, anunciado pela "strange land". Mario é o ator destinado a cumprir o resgate da princesa e desbravar a terra estranha, mas, na mesma investida está Yoshi e, também capturados estão seus amigos. Objeto-valor (princesa), oponente (Bowser) e adjuvante (Yoshi) definidos, é controverso tentar esclarecer a manipulação que leva Mario a cumprir a ação destinada com base em sua subjetividade, isto é, o querer da personagem é nebuloso à análise principalmente porque o herói não fala, não se

3 "Olá! Lamento que eu não esteja em casa, mas fui resgatar meus amigos que foram capturados pelo Bowser". - Yoshi (Tradução nossa). 
manifesta, tampouco surgem balões com texto escrito que demonstrem sua volição e sua sensibilidade. Em geral, é possível inferir que Mario cumpre seu destino porque deve, ele é o herói e a esperança final da princesa Toadstool, e não o faz de maneira forçosa, pelo contrário, seu esforço, como se demonstrará, é constante e seu empenho, forte.

$\mathrm{Na}$ fase 1 (considerando então a casa do Yoshi como fase 0), Mario já se depara com um koopa que vai ao seu encontro, uma bala gigante (Bullet Bill) e um Rex, o dinossauro, tendo que derrotar todos pulando sobre eles. Também se depara com uma moeda gigante estampada com a cara de Yoshi e um bloco quadrado com um sinal de interrogação grafado, voando e que, quando atingido, solta um cogumelo que faz Mario dobrar de tamanho. São todas essas figuras realizações da estranheza temática da Terra Dinossauro, que se estende mostrada como uma porção de montanhas enevoadas ao fundo.

Nessa fase, há ainda dois alto-falantes que explicam a possibilidade de guardar um cogumelo de crescimento em um campo acima na tela, e instruem a como segurar cascos de koopas e arremessá-los em direções específicas.

Aos 99 segundos restantes no cronômetro, a música é acelerada e um aviso sonoro extra é tocado, coagindo Mario a finalizar logo o nível cruzando as hastes que marcam o final.

Ação cumprida, o caminho esmaecido no mapa é atualizado para uma cor clara e o mini-Mario ruma para o topo de uma montanha, de onde ele pode ver todo o restante da Terra Dinossauro, e onde ele inicia a fase Palácio do interruptor amarelo (Yellow switch palace). Nela, sem inimigos, mas com tempo limite, o herói pula sobre um grande botão amarelo com um ponto de interrogação e surge uma mensagem explicando que contornos de blocos amarelos agora serão blocos amarelos sólidos, sobre os quais é possível andar e pular, ganhando poderes como o do cogumelo, que dá a estatura grande, o da flor de fogo, que permite lançar bolinhas incendiadas em direção aos inimigos, e a pena de voo, que concede uma capa usada para atingir alturas extras e planar (ver Figura 5).

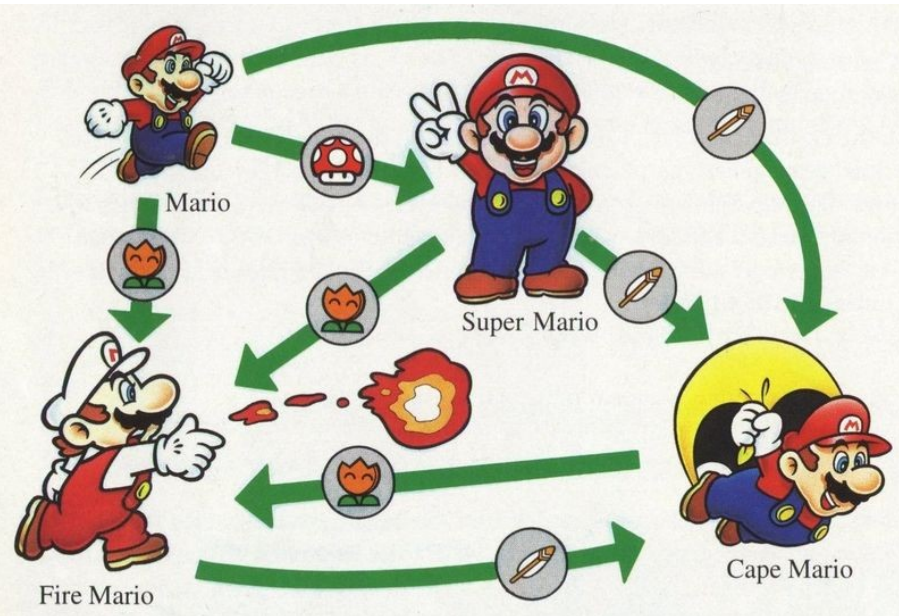

Figura 5: os poderes adquiríveis por Mario ao longo das fases.

Fonte: Super Mario Wiki. Disponível em: https://www.mariowiki.com, acesso em: 18 jan. 2019.

Seguindo o mapa, Mario inicia a fase 2, que tem o fundo completamente verde, 
como se aquela ação se passasse no interior de uma densa floresta. Ali, mais koopas aparecem, agora com colorações diferentes, além das toupeiras (monty moles), os Chucks, que são koopas mais resistentes, vestidos com uniforme de jogador de futebol americano, e as plantas-piranha (Piranha plants), que já apareceram no nível 1, aliás. Por outro lado, para balancear a numerosidade de adversários, o adjuvante Yoshi surge quando Mario acerta um bloco de interrogação. Nessa vez, o dinossauro fala a seguinte mensagem, lida em um texto no quadrado preto centralizado: "Hooray! Thank you for rescuing me. My name is Yoshi. On my way to rescue my friends, Bowser trapped me in that egg." ". Ao longo das fases, Mario pode reencontrar e reobter Yoshi diversas outras vezes.

Há, nesse nível, mais dois alto-falantes informativos, que ensinam a Mario como realizar um pulo com giro (spin jump) e avisam que duas hastes ligadas por uma fita, assim como a linha de chegada dos finais das fases, mas bem menor, marcam a metade do percurso e servem de ponto de reinício caso Mario venha a morrer. O herói também aprende a como usar as trepadeiras que crescem a partir de determinados blocos, para que escale e chegue a plataformas mais altas, a como usar os canos para chegar a lugares subterrâneos e a utilidade do interruptor azul com um "P" grafado, que transforma moedas em blocos sólidos e vice-versa, permitindo a criação de plataformas extras e outras facilidades (ver Figura 6). me prendeu nesse ovo. (Tradução nossa). 


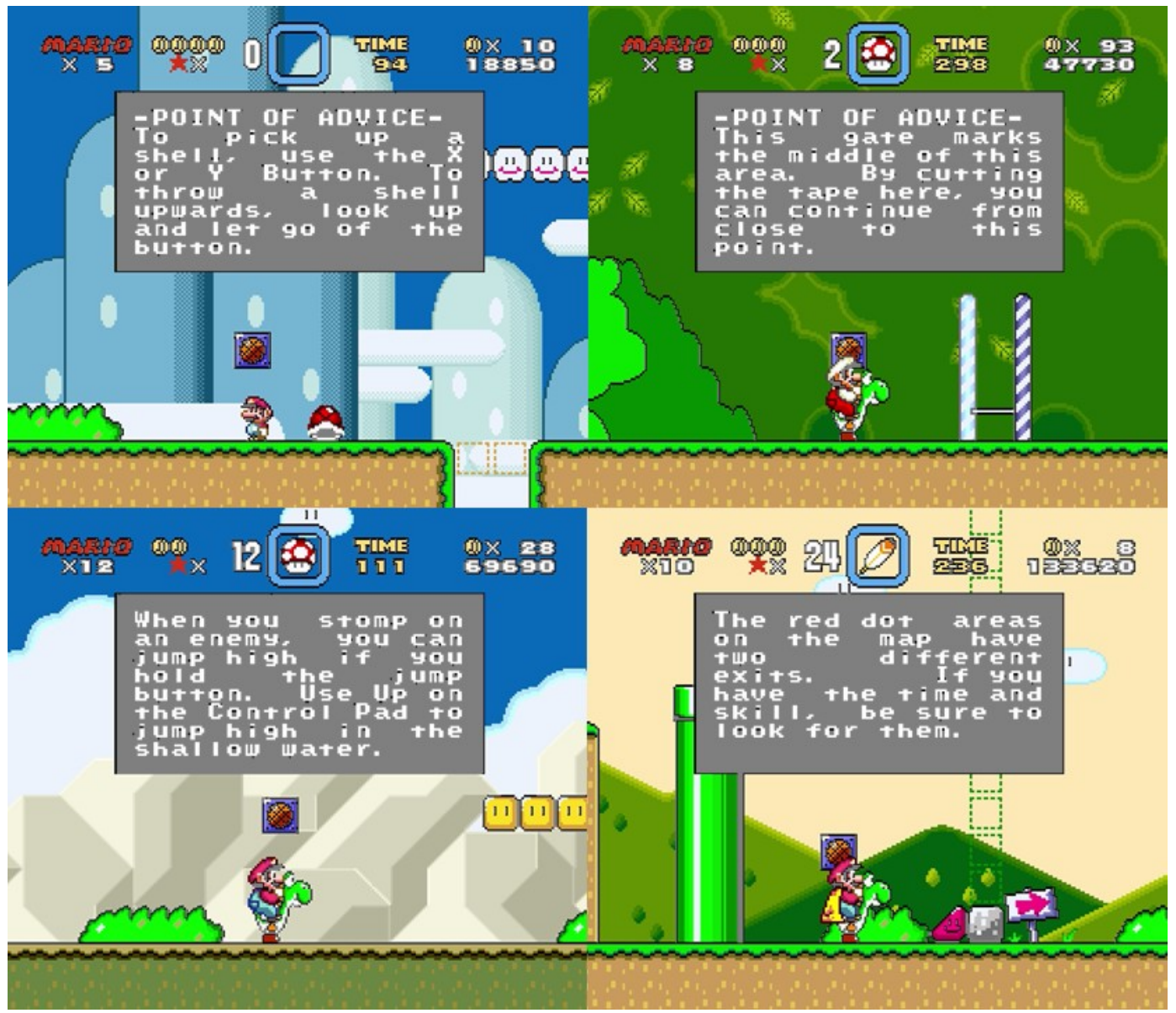

Figura 6: os informativos dos alto-falantes. Acima à esquerda, captura retirada da fase 1. Acima à direita, da fase 2. Abaixo à esquerda, da fase 3 e, finalmente, um aviso da fase 1 da segunda área da Terra Dinossauro.

$\mathrm{Na}$ fase 3, as montanhas que eram apenas fundo tornam-se frontais, e o desafio de Mario é escalá-las até a linha de chegada. Logo de início, um alto-falante ensina que, coletadas cinco moedas dragão (Dragon coins), aquelas que tem o rosto de Yoshi estampado, dentro de uma mesma fase, o herói receberá um vida a mais. Mais dois avisos são dados nesse nível: a possibilidade de pular mais alto quando se acaba de matar um inimigo e como sair da água rasa para a plataforma de terra.

Os novos desafios que Mario encontra, às vezes anunciados por esse avisos úteis, às vezes não, podem fazer com que ele perca o controle de sua ação, tocando os inimigos ou despencando em abismos. Naquele caso, a estatura de Mario Ihe permite levar dois golpes, levar dano duas vezes, antes de ser obrigado a reiniciar a fase. No último, o reinício é automático, e o herói já retorna sem nenhum poder adicional; e sem o Yoshi (ver Figura 7). 

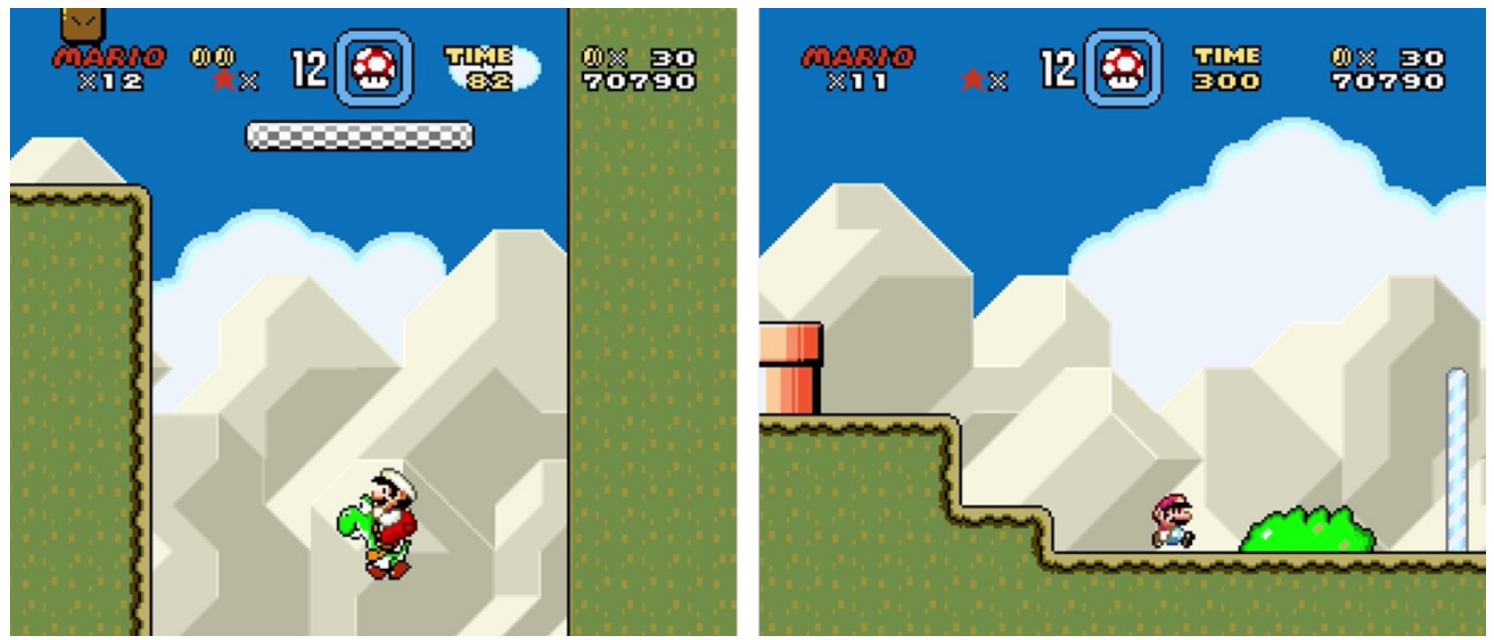

Figura 7: Mario despenca de um precipício e retorna ao jogo, a partir das hastes do meio da fase, mas sem o poder de fogo e sem o Yoshi, em sua forma mínima, com desconto de 1 vida no contador no canto esquerdo ao alto da tela.

$\mathrm{Na}$ fase 4, a dica de como emergir da água faz sentido, pois se trata de um percurso anfíbio, com peixes e ouriços gigantes como principais inimigos, além de frutas espinhosas e empilhadas como totens, que seguem Mario aonde ele for; mas há uma estrela, obtida a partir dos blocos de interrogação, que fornece ao heróis imunidade a qualquer ataque por alguns segundos.

Os avisos dos alto-falantes informam como sair de um nível que já foi completado caso Mario decida rejogá-lo, e como conquistar pontos bônus que permitem acesso a um mini-jogo, quando se totalizam 100 pontos a depender da altura da fita da linha de chegada quando Mario a cruza no final.

Por fim, a última fase é o castelo de Iggy Koopa, que, conforme avisado por um alto-falante, prendeu um dos amigos de Yoshi e, para Mario efetuar o resgate, é preciso lançar a tartaruga no fosso de lava. A lava, aliás, é um adversário espacial que surge nesse nível, assim como o enquadramento em movimento, que obriga o herói a seguir em frente, não lhe dando tempo de ficar parado e observar os arredores, e os enormes pilares de madeira que esmagam quem estiver embaixo deles.

Cumprido o resgate, uma sequência fílmica mostra Mario retirando o ovo de dentro do Castelo e destruindo a construção, sobre a mensagem escrita: "Mario has defeated the demented lggy Koopa in castle \#1 and rescued Yoshi's friend who is still trapped in an egg. Together, they now travel to Donut Land."5. O jogo então é salvo, o que significa que morra quantas vezes quiser, Mario não precisa cumprir os seus feitos atuais novamente.

$\mathrm{Na}$ fase 1 do País da Rosquinha, as tartarugas voadoras, vários Chucks arremessam bolas letais de baseball de várias direções e plantas cuspidoras de fogo configuram nossas ameaças. Para conseguir sobreviver a todos esses ataques, Mario pode obter penas de voo, que o permitem navegar aereamente longas distâncias. No final do nível, um aviso de alto-falante informa a existência de saídas secretas das fases.

Assim, o percurso de Mario continua se desenvolvendo ao longo de 7 áreas diferentes. A primeira foi a Ilha do Yoshi, e a segunda, o País da Rosquinha. Apenas com

5 Mario derrotou o maníaco Iggy Koopa no primeiro castelo e resgatou o amigo de Yoshi, que ainda está preso em um ovo. Juntos, agora eles viajam para o País da Rosquinha. (Tradução nossa). 
todas as áreas da Terra Dinossauro finalizadas, Mario pode reaver a princesa Toadstool; exceto pela facilidade de diversas passagens secretas, que lhe poupam parte da jornada.

De forma geral, percebe-se a tematização dramática do sequestro conotada tanto pelo humor de uma trilha sonora animada e veloz, quanto por inimigos que sorriem, quanto por mortes que não são definitivas, etc. As próprias cores propõem uma diversidade na expressão visual que termina por diluir o peso da missão central do herói. Em outras palavras, a pluralidade da expressão visual e sonora e dos atores enunciados e o exotismo do conteúdo compõem um tema que torna o discurso muito mais complexo que apenas uma tarefa de resgaste, que apenas uma luta do bem contra o mal encarnada por Mario e Bowser.

Bowser, aliás, só surge ao final, na área 7, chamada de Vale do Bowser. Os oponentes de Mario, vassalos da tartaruga-mor, são quem encenam as batalhas em sua esmagadora maioria. Cada área possui um chefe, como Iggy Koopa, e cada fase de cada área possui uma infinidade de koopas e outros adversários. Estes são derrotados mais facilmente que aqueles, e Bowser requer, por sua vez e por seu status, uma briga muito mais longa antes de ser subjugado.

Logo, do ponto de vista do nível discursivo,

i. o espaço é exótico e diverso, indo de montanhas a planícies, de cavernas a rios, de nuvens a lava, etc.;

ii. os atores também mantém o exotismo vívido, apresentando-se também de forma plural, animando objetos, animais e plantas de maneiras inusitadas (Mario e a princesa são os únicos humanos de fato);

iii. e o tempo é figurativizado como um empecilho, porque é limitado e letal, mas a repetição, a recursividade de se poder jogar e rejogar faz com que Mario não se preocupe se perder e falhar, colocando a ênfase sobre o "tentar".

Do ponto de vista do nível narrativo, o programa de base requer uma série extensa de programas de uso, dispostos em uma ordem específica, mas que cooperam com a competencialização do herói, dando a ele poderes eficazes, porém perecíveis e rotativos, no caso de competências pragmáticas (cogumelo, flor e pena), e definitivos, no caso de competências cognitivas (informativos de técnicas e macetes).

Na lógica figurativa há uma missão crucial de resgaste real, mas um lugar novo e estranho, com cores e sons diferentes a cada canto; na lógica agentiva, há uma missão central, mas muitas missões requeridas antes da primeira. Logo, se, por um lado, a enunciação colocou o ator Mario frente a adjuvantes e oponentes cada qual com sua identidade, sua cor e seu barulho, o herói não pode explorar e contemplar essas construções estéticas porque sua constituição ética o coage a seguir em frente e fazer tudo o que tenha que fazer o mais rápido possível.

A oposição entre a estesia e a ética dá a esta última papel mandatório até que se derrote Bowser. Aquela primeira passa a ser mais determinante apenas após Mario completar o finalíssimo nível, Funky, de uma área extra e secreta, quando toda a Terra Dinossauro ganha tons outonais e Mario ganha uma motivação extra pra vivenciar todo o exotismo (ver Figura 8). 


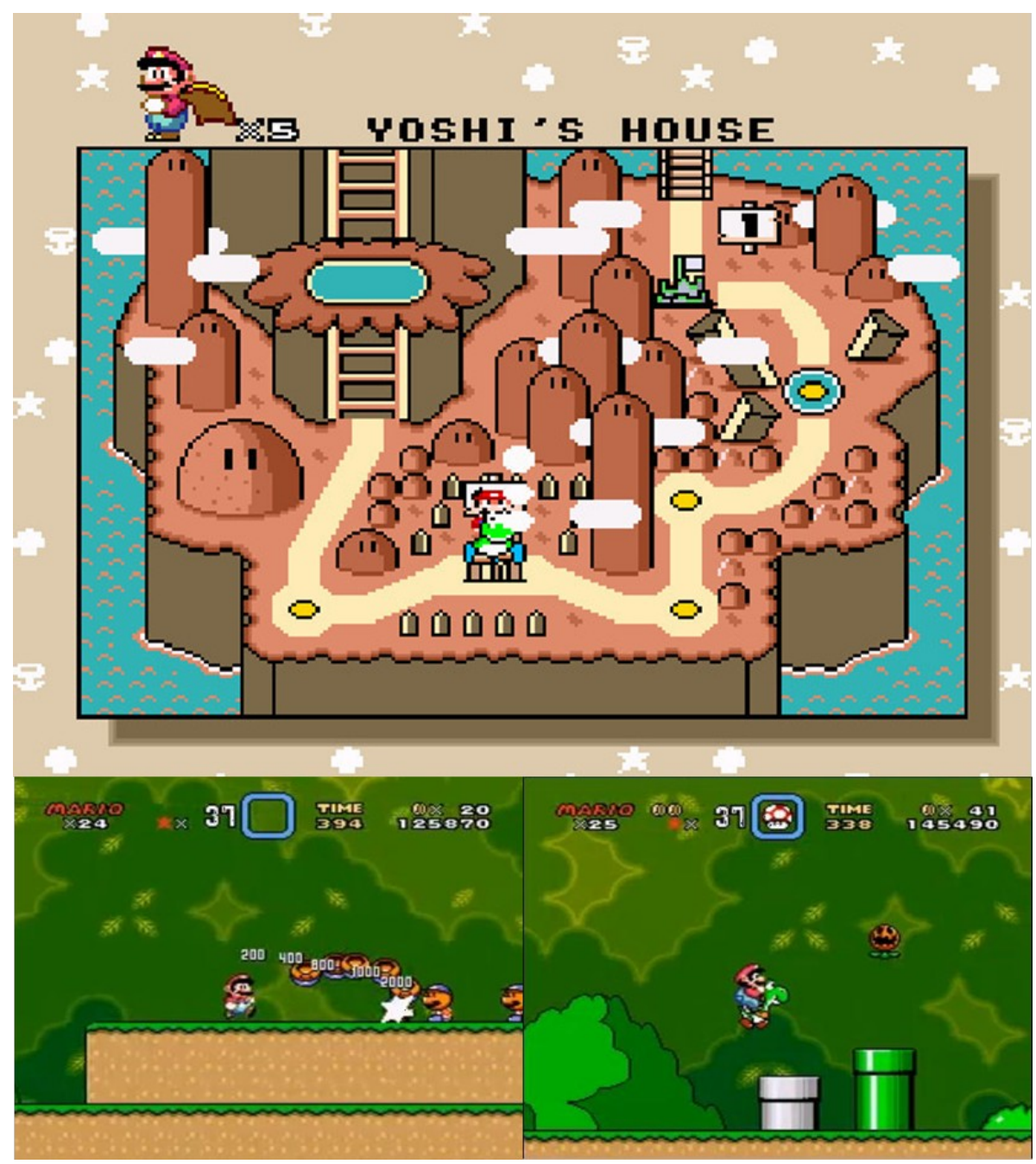

Figura 8: o modo outonal do jogo, acionado ao se cumprir o último e $96^{\circ}$ nível. Os inimigos transformam-se em elementos do arcabouço figurativo do halloween e as cores para aquelas da referida estação do ano.

Certamente, a estesia compete com a ética nesse sentido apresentado, no enunciado enunciado, mas, do ponto de vista enunciativo, ela é determinante na argumentação estabelecida entre destinador e destinatário do discurso. Isto é, para Mario, apesar de ele não dar opinião própria, o dever de salvar o dia o deixa tenso, refém do tempo e do espaço entre ele e a princesa, e a beleza estética fica em segundo plano.

Mas, para o jogador, a missão de Mario só é gratificante, só é desejável, porque o caminho até Bowser é repleto de estímulos plásticos e sonoros da expressão. O enunciatário é, em sua capacidade corporal, um ente de limites carnais sensíveis, movido por uma volição que se corrobora na estesia; jogar para vencer é necessário, para se conquistar um estatuto no enunciado e, externamente, na sociedade, mas, ao mesmo tempo, jogar é divertido porque move o corpo, vibra a carne e dá a sensação intensa de autonomia e poder.

Não se deve crer ser essa a verdade absoluta sobre essa mídia. É uma definição que dou ao corpus em um gesto consciente e direcionado de analista, que formaliza a semiótica-objeto. 


\section{Das competências do herói às competências do jogador}

Admitindo certa primazia do enunciatário sobre a personagem enunciado e, consequentemente, do narratário sobre Mario, alguns elementos que considerei há pouco, na perspectiva do enunciado enunciado, dizem respeito mais intimamente ao percurso do narratário, da enunciação enunciada.

Os avisos, por exemplo, aqueles que saem dos alto-falantes, não são vistos por Mario de fato, porque a personagem não esboça nenhuma reação quando eles surgem, pelo contrário, o jogo fica suspenso, o cronômetro é pausado. Quem lê o escrito da tela é o jogador. A impressão de Mario estar implicado no enunciado instrutivo dos alto-falantes é porque ele e o jogador encontram-se sincretizados fortemente nesses momentos. Isto é, a competencialização cognitiva fornecida ali é comum aos dois, dá o mesmo saber a ambos.

O mesmo cabe dizer da competência pragmática de Mario, do correr, do pular, do matar, do lançar fogo, do voar, etc. Como a personagem depende do controlador para obter os objetos modais que lhe dão essas competências e também depende dele para se mover de qualquer forma, é porque o narratário também tem a necessidade de adquiri-las e de colocar o ator Mario em movimento.

Saber e poder são então conquistados pelo ator sincrético Mario-jogador. Para além dessa dimensão cognitivo-pragmática, esses sujeitos começam a se distinguir com mais nitidez. Por exemplo, o querer de Mario é demasiado átono, a ponto de compreendermos suas motivações como meras coerções cristalizadas socioletais do seu mundo imaginário, relativas, certamente, às nossas próprias coerções sociais - afinal, o mundo natural serve de base cultural para qualquer produção discursiva que se efetue nele.

O querer do jogador, por outro lado, é a vitória, é isso que o enunciatário busca. Novamente, essas características volitivas desse sujeito remetem a um cenário cultural, em que se reconhece um estereótipo de jogador, um sujeito social que deseja ser valorizado por conquistar méritos próprios em videogames. A enunciação constrói seu enunciatário a partir desse estereótipo. Isto é, ela oferece o valor da vitória a um sujeito que já está disposto a conquistá-la, oferece um jogo a um sujeito já-jogador.

Essa oferenda comunicativa estabelece-se no contato actorial entre enunciador e enunciatário, em que aquele se coloca frente a este a partir de uma "roupagem" específica, a partir de uma maneira de ser, de ver, de dizer, etc. Seja qual for sua intenção com o destinatário (incitar, capacitar, sensibilizar, ordenar, julgar), o enunciador sempre adota uma posição em relação a ação que se cobra. Isto é, antes de toda a coação do destinador do enunciado sobre o destinatário, há, na base, o estabelecimento de um paradigma valorativo, com o qual aquele primeiro ator pretende que o segundo comungue.

A pretensão de convencer o outro a adotar seu sistema de valores esquematiza-se em um fazer persuasivo. $\mathrm{O}$ enunciador diz algo no qual ele espera que o enunciatário acredite. Naturalmente, é o contrato fiduciário que garante a efetividade dessa adesão (GREIMAS; COURTÉS, 2013, p. 208-209). Tudo o que é expresso pelo texto é apreendido como verdadeiro pelo enunciatário.

No game, a vitória só é conquistada se o jogador acredita que ela vale a pena a 
princípio; esse valor quem dá é a enunciação, pelo esforço argumentativo do enunciador. Esse paradigma valorativo é a expressão da conduta do sujeito da enunciação e de sua visão de mundo. A investida mais profunda do enunciador é precisamente "vestir" o enunciatário de sua mesma conduta, convencendo-o a isso pelos meios necessários.

No videogame, basta esclarecer que a vitória só se alcança por meio dessa vestimenta, e por nenhuma outra. O único caminho é o enunciatário se adaptar a tal maneira de ser e de fazer para cumprir seu papel no jogo.

Dessa maneira, o enunciatário é determinado pelo objeto-valor que o motiva, pelo ethos do enunciador, imprescindível à conquista, e por um passado estereotipado, recuperado do circuito sociohistórico mais ou menos difuso no qual se insere o texto.

A vitória conquistada valida a habilidade do jogador. Essa habilidade, no caso de SMW, é relativa tanto ao patamar cognitivo - o jogador soube bem compreender as dinâmicas dos obstáculos do enunciado -, quanto ao patamar pragmático - o jogador foi capaz de controlar bem a personagem.

Aí, necessita-se distinguir essa competência pragmática do controle daquela dos poderes adquiridos no enunciado enunciado. Estes são poderes técnicos, são passageiros, rotativos, basta tocar o cogumelo, a flor e a pena, e objetivamente conquistou-se o poder. Já aquela competência do jogador não é apenas técnica, mas subjetiva. Ela é tão crucial para a premiação do jogador como vencedor, que a ter é uma questão de moldar a própria identidade. Mais especificamente, de moldar suas habilidades motoras, corporais.

Assim, a volição do jogador é um dos constituintes de sua subjetividade e o lança ao ato de jogar, à operação prática. O outro ponto que sustenta o sujeito é sua capacidade sensível, a estesia, o modo como ele, construído pela enunciação, afeta-se pelos elementos sensibilizantes.

O grau de sensibilidade foi observado por Landowski como uma competência (Cf. LANDOWSKI, 2014, p. 50). Para o autor, a competência estésica difere-se das competências modais da semiótica standard (querer, dever, poder e saber), porque não se engendraria em um percurso narrativo programático, isto é, um caminho da ação prescrito para ser cumprido sem desvios nenhum. O fato é que, olhando videogames, a capacidade sensível, o corpo-competência, é uma modalidade sim para o cumprimento da ação. Quanto mais competente for o corpo do enunciatário, mais chances de sucesso ele tem. A diferença reside na flexibilidade da sanção.

Caso esse sujeito, no momento de controle das personagens, não saiba o que deve fazer, não tenha adquirido os poderes necessários ou não queira, simplesmente, cumprir nenhuma destinação, a ação sequer avança, o jogo não se finda, o timer "estoura" ou o console entra em stand-by.

Caso o sujeito tenha o querer, o saber e o poder, mas ainda falhe em controlar o joystick, em responder rápido o suficiente aos perigos do enunciado, colocando-se nas corridas de fuga ou nos contra-ataques, o jogo avançará narrativamente, dando à sanção negativa do fracasso o eufemismo da tentativa, do aprendizado, já que ela configura uma nova chance para o jogador.

Logo, a competência estésica é modal, porque é uma extensão da competência pragmática, é a constituição de habilidades do sujeito, forjadas no treino. Mas justamente por ser sensível, não pode ser tratada, simplesmente, como dimensão pragmática. Não 
há facilidade na sua aquisição, ela não está acabada, pronta para ser "colhida" pelo enunciatário, tal como o cogumelo que faz crescer. É preciso, no controle interativo do videogame, saber usá-la, além de tê-la. Em suma, ela não é um elemento de ordem extensa, mas de ordem intensa, não é um componente do mundo integrado pelo sujeito, mas um componente do sujeito lançado para transformar o mundo, é uma força interior, pessoal e intransferível, que conjuga poderes e saberes de maneira subjetiva.

Essa complexidade de classificação é interessante por revelar uma hierarquia de nível de amplitude das competências. Há competências cognitivas e pragmáticas que são unicamente objetivas; o caso do cogumelo apanhado, do caminho descoberto, do mapa conquistado, do segredo desvendado, etc. Estas são habilidades, sobretudo ligadas à personagem do enunciado enunciado, e ditam o ritmo segundo o qual a narrativa desse ator se desenvolve.

A estesia é uma competência subjetiva, porque durativa e não interfere no ritmo da história da personagem, apenas no ritmo narrativo do enunciatário. O jogador pode fracassar independentemente se Mario está com a capa de voo ou a flor de fogo. Suponhamos a morte do herói ao longo de uma fase de jogo. Mario irá retornar sem problema algum à mesma fase logo em seguida ao fracasso do jogador. Desconta-se, dele, apenas uma vida, registrada numericamente no alto da tela. Inclusive, a vida não é referida pelo texto como "vida", mas como "um Mario extra" (ver Figura 9).

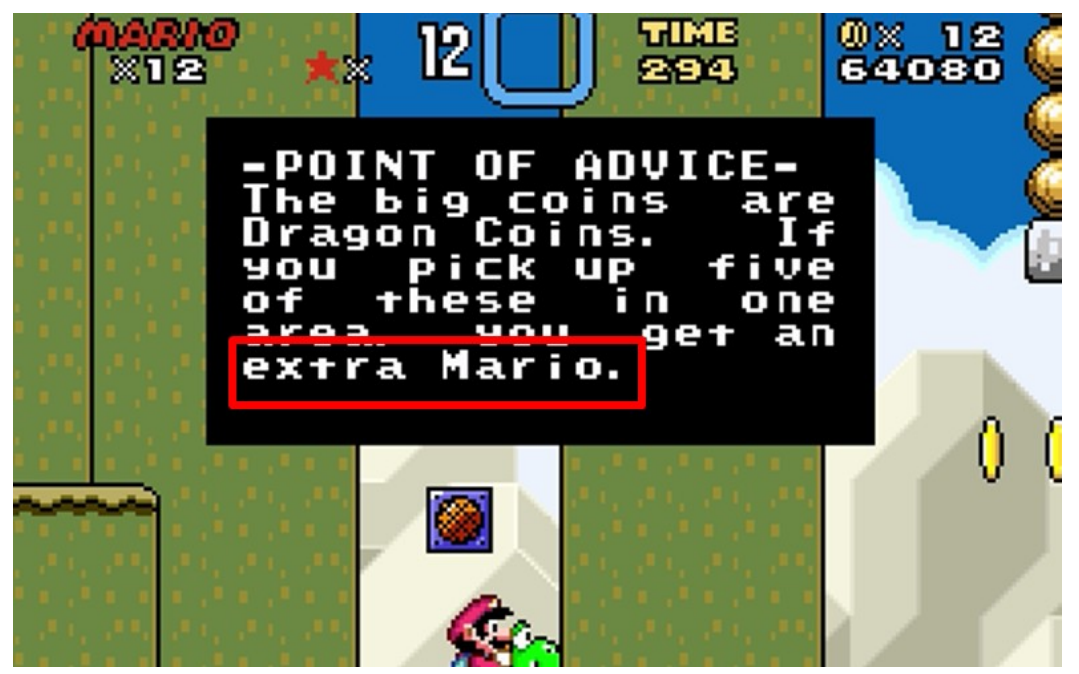

Figura 9: o alto-falante avisa que, coletadas cinco moedas dragão em uma mesma fase, o jogador obterá um Mario extra.

\section{0 percurso narrativo do jogador de Super Mario World}

Quanto ao percurso narrativo, o jogador chega à mesma tela inicial em que Mario foi apresentado, e visualiza o comportamento exemplar do herói na sequência animada. Aquela cena do princípio é um discurso instrutivo, a fim de competencializar o jogador, fazendo-o ciente das possibilidades articulatórias de Mario, a fim de que ele inicie o jogo guiando os controles para realizar aqueles movimentos já anunciados.

Então, como mais uma competência cognitiva, o jogador é informado sobre a 
"estranha terra" a que o herói chega e na qual ele irá resgatar a princesa de Bowser.

O mapa apresenta-se com a casa do Yoshi no centro e os dois primeiros níveis. Nesse ponto, é necessário observar o controle joystick do Super NES, assim como da nova versão Super NES Classics, que possui dois botões centrais, estreitos e pequenos, e duas áreas laterais, uma contendo quatro botões direcionais organizados em forma de cruz e a outra, quatro botões alfabéticos, além de dois gatilhos frontais para cada lado, localizados na curva do joystick (ver Figura 10).

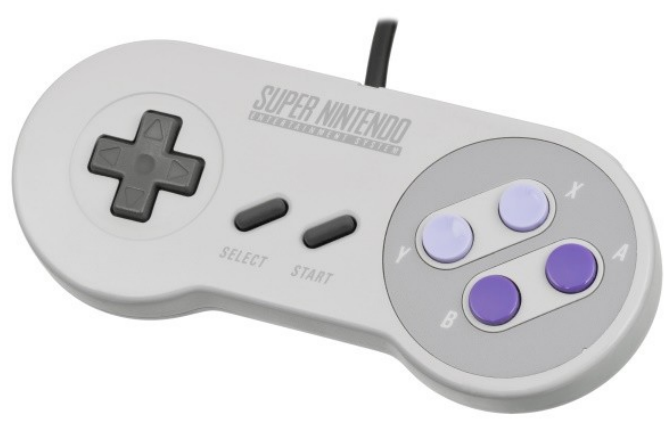

Figura 10: o controle do console Super Nintendo.

Levar em conta o objeto-suporte é imprescindível para a compreensão do corpo do enunciatário, pois sua contraparte, o enunciador também possui um corpo e que também pode ser tratado como um conjunto não de competências especificamente, mas de coerções corporais. Falar em "corpo do jogo" ou em "corporeidade do objeto-suporte", é se referir à dimensão material dos aparatos físicos com os quais o jogador entra em contato. Sendo esses aparatos previstos pela enunciação, já que são o lugar em que o próprio texto se inscreve, não sendo facultativos à comunicação dos videogames, suas dimensões são controladas também pelo mesmo ato enunciativo. O tipo de toque e pegada que o joystick tem é determinante na apreensão sensível do jogador.

Em outras palavras, as coerções corporais do enunciador, que são manipulações sensíveis, determinam o ganho de competências corporais pelo enunciatário. A manipulação objetal inicial do jogo é o pressionamento dos botões direcionais, que se corrobora pela representação plástica de setas para a esquerda e para a direita, que levam aos níveis 1 e 2 (ver Figura 11).

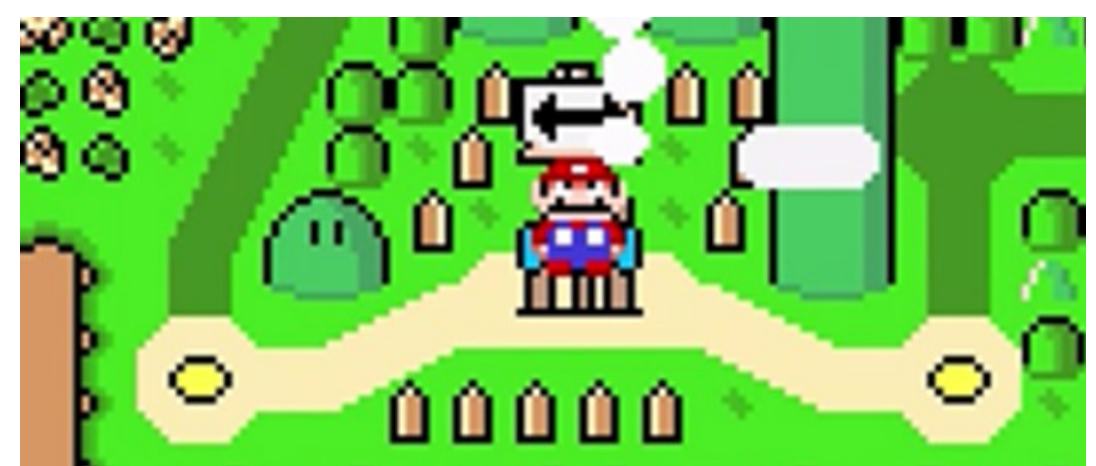

Figura 11: as setas corroboram a manipulação para o jogador pressionar os direcionais no joystick. 
Entretanto, tentado a pressionar os botões redondos alfabéticos, o jogador coloca o narratário na fase 0 , onde ele lê a carta de Yoshi. O único caminho após isso é selecionar direcionalmente qual o próximo nível a ser iniciado.

Então, na tela de dentro das fases, a quantidade de informações enunciadas sobre o estado do jogo é ampla e localizada superiormente. Há uma contagem de Marios disponíveis, um contador de moedas dragão coletadas na mesma fase, a quantidade de pontos bônus, a caixa de power-up extra, o cronômetro e o contador de moedas comuns (ver Figura 12).

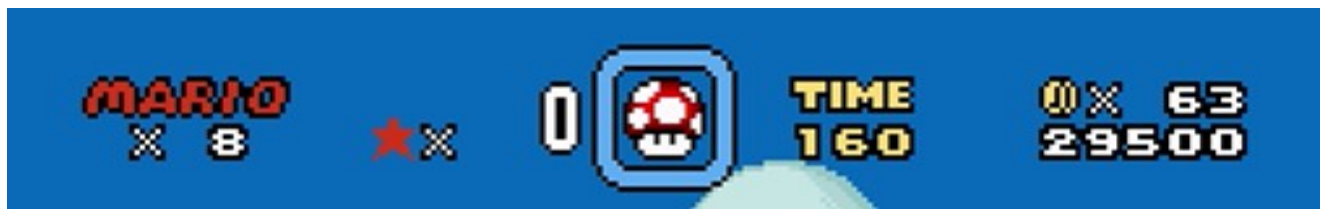

Figura 12: os monitores do estado do jogador.

Esses monitores de estado auxiliam no controle do progresso do jogo, contribuindo, sobretudo, com o gerenciamento que o jogador tem sobre a quantidade de vezes que pode morrer antes de atingir o game over, o reinício da jogada.

Os alto-falantes também configuram não um mero informativo, mas o ganho dos saberes necessários, que, como apontado, são comuns entre Mario e o narratário; eles são a voz do narrador sendo enunciado. É graças a esses informativos que se pode, de fato, falar em um sujeito da enunciação enunciado, eles são a explicitação, a figurativização, da presença do sujeito da enunciação na própria matéria narrada.

Todo o resto do progresso ao longo da Ilha do Yoshi é aquele já descrito, mas a peculiaridade em analisá-lo do ponto de vista do narratário é observar como essa primeira área serve para sensibilizar o corpo do enunciatário. Além de corroborar com a exploração de diversas figurativizações espaciais, revestimento do tema exótico, a diversidade de inimigos apresentados e de espaços adversos oferece uma paleta de controles do jogador sobre a articulação motora de Mario:

i. o primeiro nível tem os tons bem mais pastéis e explora uma sorte de inimigos específicos: os dragões Rexes, as plantas piranha, as balas gigantes e os koopa, em suas versões com casco, sem casco e Chuck;

ii. o primeiro palácio do interruptor, o amarelo, mostra-se como um nível naturalmente conquistado após o cumprimeiro do primeiro, mas, nas outras áreas da Terra Dinossauros, todos os interruptores de blocos são alcançados apenas por meio de passagens/saídas secretas. Isto é, o jogo instrui a existência de um lugar que preenche os blocos contornados nos níveis, e oferece o primeiro "de graça";

iii. a fase dois conta com as toupeiras, com as trepadeiras, com as alas subterrâneas e com o Yoshi;

iv. a terceira explora as quedas verticais e as plataformas móveis de diversos tipos;

v. a quarta adentra o espaço aquático, introduzindo os inimigos marinhos e a estrela de imunidade;

vi. o castelo de lggy, por sua vez, introduz a lava e as colunas de madeira gigantes, além de sediar o primeiro embate contra um chefe. 
Do ponto de vista interno à Ilha do Yoshi, esses níveis possuem diversidade mais por uma questão de fazer manutenção do tema exótico do que competencializar estesicamente. As competências ofertadas são, na realidade, mais do tipo cognitivo. Se é possível elencar uma modulação do corpo do enunciatário, ela tem a ver com a música acelerada quando o tempo restante é menor que 100 segundos, que promove a aceleração do andamento.

Mas, quando comparado ao primeiro nível da segunda área, percebe-se como a densidade de inimigos aumenta. $\mathrm{Na}$ área 1, os níveis apresentam inimigos de maneira esparsa, distantes, permitindo ao narratário enfrentá-los individualmente. No País da Rosquinha, tudo que é danoso surge muito mais próximo, inimigos e adversidades espaciais (ver Figura 13).

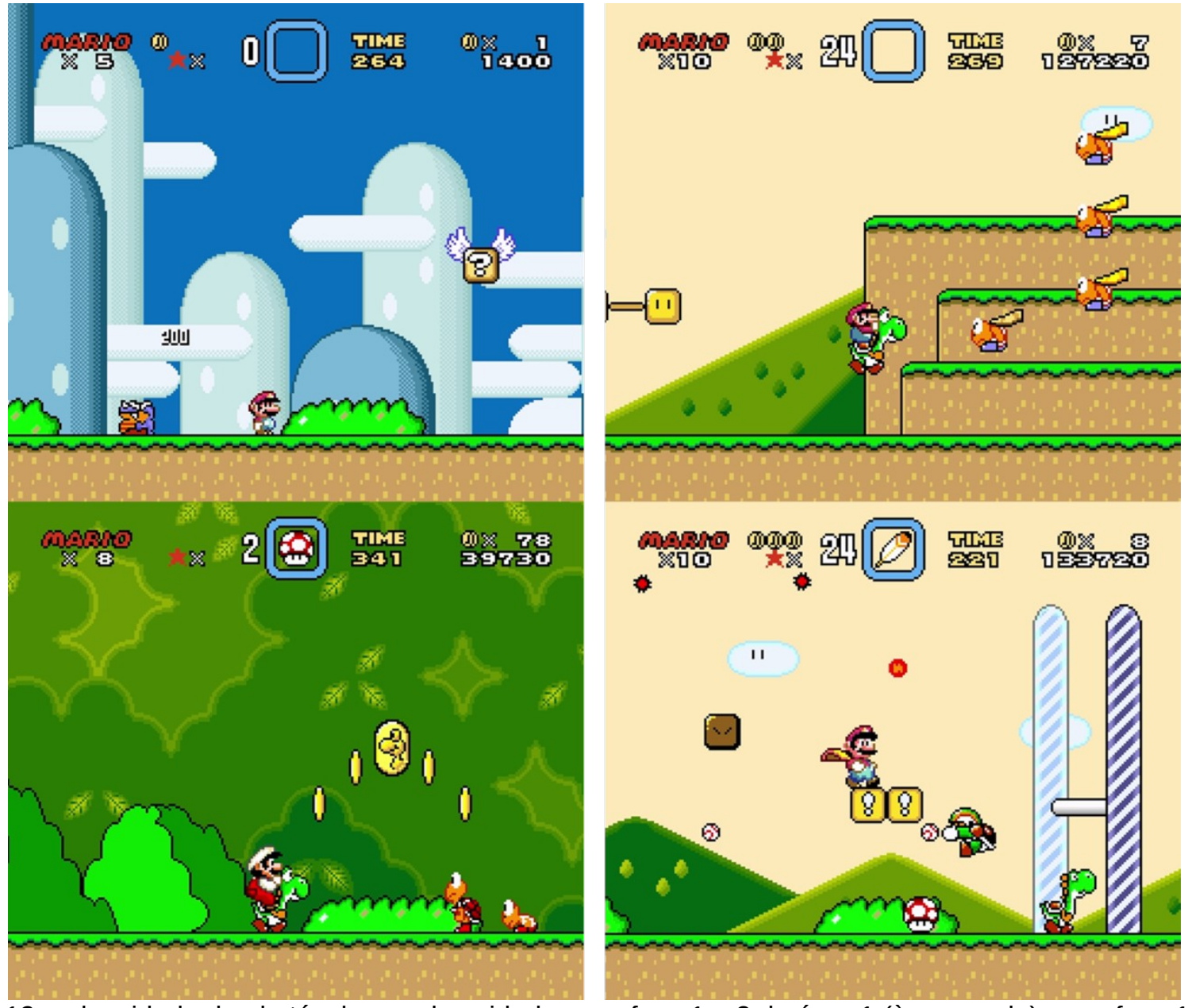

Figura 13: a densidade de obstáculos e adversidades nas fase 1 e 2 da área 1 (à esquerda), e na fase 1 da área 2 (à direita).

A complexificação gradual da dificuldade que esses inimigos configuram é uma estratégia de competencialização estésica. Superar essas adversidades depende das reações do narratário, medidas em duração, de ordem extensa, e em potência, de ordem intensa, pensando na perspectiva tensiva da semiótica do discurso. Trata-se do quão rapidamente ele corre, foge, desvia, ataca, etc. É preciso ajustar-se às oscilações 
interativas que os perigos configuram, também medidas em extensidade e em intensidade.

Por ajustamento, Eric Landowski refere-se a um tipo de interação entre dois atores que se adaptam mutuamente ao fazer um do outro, compondo uma ação conjunta, não manipulada unilateralmente, mas motivada dos dois lados (Cf. LANDOWSKI, 2014, p. 4760). Um desses atores é o narratário e, por extensão, a personagem controlada. O outro corresponde seja ao inimigo de inteligência artificial, seja a um adjuvante, também artificial, seja ao próprio espaço, actorializado em seus aspectos danosos ou benéficos à saúde do ator enunciado.

É fino o limite entre um regime de ajustamento e um regime de programação, em que não há margem de adequação, apenas de resposta a um roteiro previamente dado (Cf. LANDOWSKI, 2014, p. 21-25, 52). Nas situações isoladas dos níveis analisados de SMW, a programação vigora, pois a lógica causal é explícita, é informada pelo alto-falante ou faz parte dos ataques que a sequência da tela inicial demonstrou. Pode ainda ser o caso de uma lógica causal semelhante à do mundo natural, referência básica para um enunciado culturalmente marcado.

Pode-se compreender como uma lógica bastante causal os seguintes predicados que surgem ao longo da Ilha do Yoshi:

- Mario mata um inimigo pulando sobre ele.

- Mario não pode ser atingido por inimigos ou projéteis lançados por inimigos, senão morre.

- Mario não pode tocar na lava, senão morre.

- Mario não pode despencar de um precipício, senão morre.

Gradualmente, alguns inimigos com funcionamento distintos são apresentados:

- Os Rexes precisam de dois golpes para ser derrotados.

- Os Chucks precisam de um golpe com giro para ser derrotados.

- Iggy precisa ser empurrado contra a lava para ser derrotado.

Mas, no País da Rosquinha, nada avisou Mario que:

- Quatro koopas voadres vêm na direção de Mario ao mesmo tempo em que dois Chucks lançam bolas de baseball.

Certamente, não é possível derrotar todos esses inimigos, então é preciso decidir quem atacar e de quem desviar. É necessário ainda, como de praxe para Mario, calcular o impulso e a distância tomada para poder saltar, golpear, ou quando cessar a aceleração e esperar o perigo passar. É preciso saber quando realizar o movimento, se é possível correr antes do ataque ou se o único caminho é a retensão do salto.

Os termos "quando", "impulso", "distância", "antes" e "se" revelam as variações tensivas do momento propício da ação, do acontecimento, conforme a acepção de Zilberberg (Cf. ZILBERBERG, 2011). O problema, para o narratário, é que as dimensões do acontecimento não são ensinadas no tutorial; nem poderiam, já que

O acontecimento, na qualidade de grandeza tensiva, deve ser apreendido como uma inversão das valências respectivas do sensível e do inteligível. Marcado por um andamento rápido demais para o sujeito, o acontecimento leva o sensível à incandescência e o inteligível à nulidade. (ZILBERBERG, 2011, p. 190). 
De um possível ponto de vista da análise, nessa inversão entre sensível e inteligível, não há nada de muito inusitado, pois a combinação entre extensidade e intensidade não gera uma infinidade de perfis tensivos. Pelo contrário, todas as realizações estão potencializadas no algoritmo, no roteiro de um game.

O efeito de sentido para o narratário inexperiente, porém, é o da concessão, de que ele foi pego de surpresa pelo programa narrativo que se desenrola e que seu ajustamento pode agir como regente, como destinador mesmo, de cada ação efetuada, tal como se o destino absoluto do restante do game dependesse de sua atuação.

Esse efeito de sentido provém do estilo veredictório colocado pelo videogame, que não se "vende" como um filme a ser assistido, mas como uma ação a ser interpretada, no sentido teatral. O ineditismo aparente da ação, o inusitado, o aleatório, etc., são modos de presentificação do acontecimento, se tomado o enunciatário como vórtice do campo de presença. A garantia da estratégia enunciativa é a confiança do enuncitário na ideia de o enunciador lhe delegar autonomia sobre sua própria percepção no desenvolvimento da ação.

Em uma metáfora com o teatro, o game é uma interpretação advinda de um texto apenas parcialmente ensaiado pelo ator, tal qual o tutorial parcial dado ao jogador. $O$ improviso é a palavra-chave, e se reconhece o sucesso do sujeito pela medida em que seu improviso assemelha-se a um texto pensado, escrito e revisto. No teatro, 0 enunciador é a figura do discurso encarnada no ator, e o julgador da ação é o destinatário, a plateia. No videogame, ao contrário, o enunciador também julgador não se mostra senão pelas instruções deixadas na tela, e o destinatário do discurso e portador do ajustamento de improviso é o jogador.

Mas este é um "jogo sujo", porque o jogador é iludido a crer em uma autonomia que não tem. No espaço fiduciário, essa ilusão transforma-se em certeza, à medida que o videogame abandona o início da sintaxe de sua experiência e segue adiante, despreocupando-se com a tutoria oferecida ao jogador, e ele ganha a plena capacidade de sentir as oscilações tensivas de um acontecimento e de se sobressair às adversidades mediante o pleno controle sobre a personagem e sobre o joystick.

Último ponto da metáfora: como o ator tem o palco Ihe limitando a ação, o jogador tem o texto objetal. Os ineditismos, inusitados e aleatórios sensíveis desse texto fazem o sujeito sentir-se responsável absoluto pelas respostas que ele precisa dar por meio do controle. Quando ele alinha essa resposta àquela que a enunciação já esperava e descobre quase todas (se não todas) as interações que devem ser estabelecidas com o espaço sensível para se chegar à vitória, ele descobre os limites do horizonte sensível, os limites do "palco" da interação.

\section{A duração do ajustamento e a duração da programação}

Quando completamente competente, o jogador, agora soberano, apenas cumpre todo o conhecimento e sensibilidade acumulados, e encerra a ação, vai em frente, sem perder, sem retornar, sem hesitar. Parte desse conhecimento, desse saber do que Mario é capaz, encontra-se na cena inicial, da primeiríssima tela do jogo. O aspecto da performance que bem se sanciona é terminativo. 
Ao contrário, até que se chegue aí, o jogador dá à competencialização o aspecto durativo, porque ela não se encerra rapidamente, não é certa em seu destino, é sinuosa, recursiva, até confusa. Por ser da ordem do sensível, do acontecimento, seu tempo não é regrado, impotência do sujeito frente à "ferocidade" das adversidades enunciadas não tem prazo para se encerrar.

Não obstante, é do interesse do projeto enunciativo que o jogador se detenha exaustivamente nesse estágio, para que ele não se frustre muito adiante no jogo, achando que o videogame é injusto.

Via de regra, a performance, de programação terminativa, figura mais ao final do jogo e a competencialização, de ajustamento durativo, figura mais ao início do jogo. Mas as duas não existem em regime de exclusividade, e sim de dominância. A todo o momento, a toda a área e a toda a fase, a cada pequeno programa de uso, o jogador sente o corpo do jogo e assume a responsabilidade da ação, dando fim à duratividade sensível em prol da finalidade inteligível.

É ao longo das fases e das áreas, conforme elas avançam, que menos o jogador necessita ainda aprender coisas sobre SMW. É esse momento de estabilidade e de segurança entre as reações motoras, os estímulos materiais, os valores figurativos e os afetos, aquele em que os limites do "palco" são reconhecidos.

É quando o regime do ajustamento atenua-se ao seu mínimo e o regime da programação retorna, com a certeza e a confiança plena no enunciador e no enunciado. É uma programação que não foi apenas dita e delegada, mas experienciada. $O$ efeito de sentido é o sujeito tê-la conquistado sozinho, independente de um narrador o instruindo e o deixando sentir o jogo.

Esse sujeito que obtém a compreensão da lógica causal do mundo enunciado e da cena predicativa, da enunciação em ato, por meio de sua "autonomia" e de sua competência estésica, não apenas assume o papel temático de jogador com incontestável propriedade, deixando irrevogavelmente de ser inexperiente, mas está no caminho para incorporar um ethos, uma figura da cultura, um comportamento socialmente reconhecido: o competidor.

\section{Considerações finais}

Do que se pode observar nas reflexões anteriores, há muita produtividade para a semiótica discursiva partir do texto-enunciado para a reconstrução da cena predicativa prototípica de uso desse texto. Mantemos o escopo discursivo, a predileção textual, mas adentramos um terreno da usabilidade, da vida prática, como nos convida os desafios da contemporaneidade, no intuito de avançar nosso campo ao mesmo tempo em que refinamos e revemos nossa própria metalinguagem, sem perder as configurações linguísticas da nossa base.

Para dar mais acabamento ao trabalho apresentado, ainda caberiam considerações mais profundas acerca da semiótica tensiva, integrando, de fato, os conceitos zilberberguianos ao objeto de análise, considerando, além do andamento e da percepção sensível do sujeito como vértices da significação, o fazer missivo que se opera, contraponto as características de Mario e do jogador. 
Ainda mais, é preciso investigar o jogo SMW como um todo, mesmo que um artigo não traga todas as áreas jogadas, pois, ainda que por considerações breves de sua completude, é possível atingir maior precisão para apontar, por exemplo, a atenuação dos ajustamentos em detrimento da fixação de programações. Deve haver um momento ao longo das 96 fases do jogo, em que as dinâmicas de ataques deixam de ser inovadoras e passem a se repetir consideravelmente.

No mais, evidenciou-se a relação íntima das fases do programa narrativo canônico às questões de operação prática, aliando-se ainda apontamentos de Landowski, sobre o que ele, em sua visão, chamou de outros regimes de ação que não o da programação, este de que se ocupou a semiótica standard. Na verdade, justamente por essa relação íntima apontada, o ajustamento e a estesia não só "cabem" no nível narrativo como o conhecemos, como é, no caso dos videogames, responsável por fazê-lo andar.

\section{Referências}

ANGELO, J. R. C. Análise semiótica de videogames: uma aposta na interdisciplinaridade. 2015. 124f. Dissertação (Mestrado em Estudos de Linguagem), Programa de PósGraduação em Estudos de Linguagem, Universidade Federal Fluminense, Instituto de Letras, Niterói, 2015.

CALLIARI, M.; MOTTA, A. Código Y: decifrando a geração que está mudando o país. São Paulo: Editora Évora, 2012.

DISCINI, N. Corpo e estilo. São Paulo: Contexto, 2015.

ERNICA, R. R. Ensaio semiótico sobre a narratividade nos jogos digitais. 2014. Dissertação (Mestrado em Estudos Linguísticos e Literários em Inglês), Programa de PósGraduação em Estudos Linguísticos e Literários em Inglês, Faculdade de Filosofia, Letras e Ciências Humanas, Universidade de São Paulo, São Paulo, 2014.

FONTANILLE, J. Pratiques sémiotiques. Paris: Presses Universitaires de France, $2008 \mathrm{a}$.

FONTANILLE, J. Práticas semióticas: imanência e pertinência, eficiência e otimização. In: DINIZ, Maria Lúcia Vissotto Paiva; PORTELA, Jean Cristtus (orgs.) Semiótica e mídia: textos, práticas, estratégias. Bauru: UNESP/FAAC, 2008b, p.15-74.

FONTANILLE, J. A semiótica hoje: avanços e perspectivas. Estudos semióticos. [on-line]. Editores responsáveis: Ivã Carlos Lopes e José América Bezerra Saraiva. Volume 12, Número 2, São Paulo, Dezembro de 2016a, p. 1-9. Disponível em: http://www.revistas.usp.br/esse/article/view/127608. Acesso em 01 ago. 2017.

FONTANILLE, J. Corpo e sentido. Tradução de Fernanda Massi e Adail Sobral. Londrina: Eduel, 2016b.

GREIMAS, A. J.; COURTÉS, J. Dicionário de semiótica. 2ª ed. São Paulo: Contexto, 2013. 
LANDOWSKI, E. Interações arriscadas. Tradução de Luiza Helena da Silva. São Paulo: Estação das Letras e Cores, 2014.

OLIVEIRA, T. M. de; MARINHO, K. A. R. A construção do conhecimento no 'Alternate Reality Game'. Signo pensam, v. 29, n. 57, Bogotá, julho de 2010, p. 538-551. Disponível em: http://www.scielo.org.co/scielo.php?script=sci_arttext\&pid=S012048232010000200037\&lng=en\&nrm=iso. Acesso em: 02 ago. 2017.

PORTELA, J. C. Semiótica midiática e níveis de pertinência. In: DINIZ, Maria Lúcia Vissotto Paiva; PORTELA, Jean Cristtus (orgs.) Semiótica e mídia: textos, práticas, estratégias. Bauru: UNESP/FAAC, 2008, p. 95-115.

SOUZA JÚNIOR, P. C. de. A interatividade no jogo eletrônico: Shadow of the Colossus. Estudos semióticos [on-line]. Editores Responsáveis: Francisco E. S. Merçon e Mariana Luz P. de Barros. Volume 5, Número 2, São Paulo, novembro de 2009, p. 52-59. Disponível em: http://www.revistas.usp.br/esse/article/view/49247/53329. Acesso em: 01 ago. 2017.

SOUZA JÚNIOR, P. C. de. Entre jogador e leitor: análise semiótica da adaptação de Assassin's Creed para romance. 2015. Dissertação (Mestrado em Estudos de Linguagem), Programa de Pós-graduação em Estudos de Linguagem, Universidade Federal Fluminense, Instituto de Letras, Niterói, 2015.

SUPER Mario world. Desenvolvimento de Nintendo Entertainment Analysis \& Development. Publicação de Nintendo. Platarforma: Super Nintendo Entertainment System (Super NES); Super Nintendo Entertainment System Classic Edition (Super NES Classic), [1 console Super NES Classic], 1990.

ZILBERBERG, C. Elementos de semiótica tensiva. Tradução Ivã Carlos Lopes, Luiz Tatit, Waldir Beividas. São Paulo: Ateliê editorial, 2011. 
hetp://periodicos.letras.ufmg.br/index.php/textolivre
Linguagem e Tecnologia Belo Horizonte, v. 12, n. 1, p. 85-111, jan.-abr. 2019 - ISSN $1983-3652$ DOI : $10.17851 / 1983-3652.12 \cdot 1.85-111$

\section{ANEXOS}

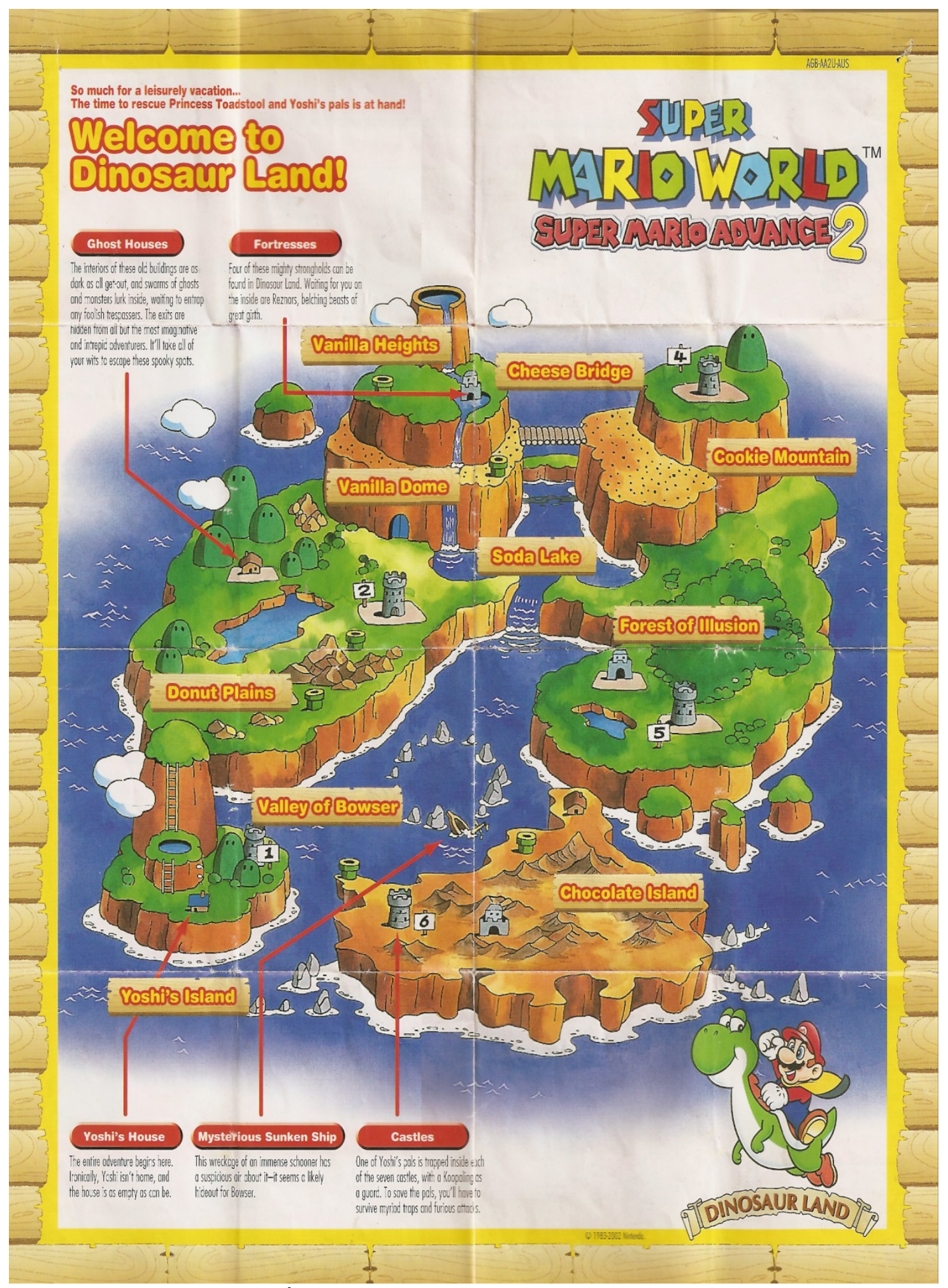

Fonte: Super Mario Wiki. Disponível em: https://www.mariowiki.com/, acesso em 18/01/2019. Ambos os encartes são da versão de Super Mario World para o console Game Boy Advance, de 2001.0 primeiro, mostra a Terra Dinossauro, o segundo, os inimigos de Mario. 
fing

Linguagem e Tecnotogia Belo Horizonte, v. 12, n. 1, p. 85-111, jan.-abr. 2019 - ISSN 1983-3652

DOI : $10.17851 / 1983-3652 \cdot 12 \cdot 1 \cdot 85-111$

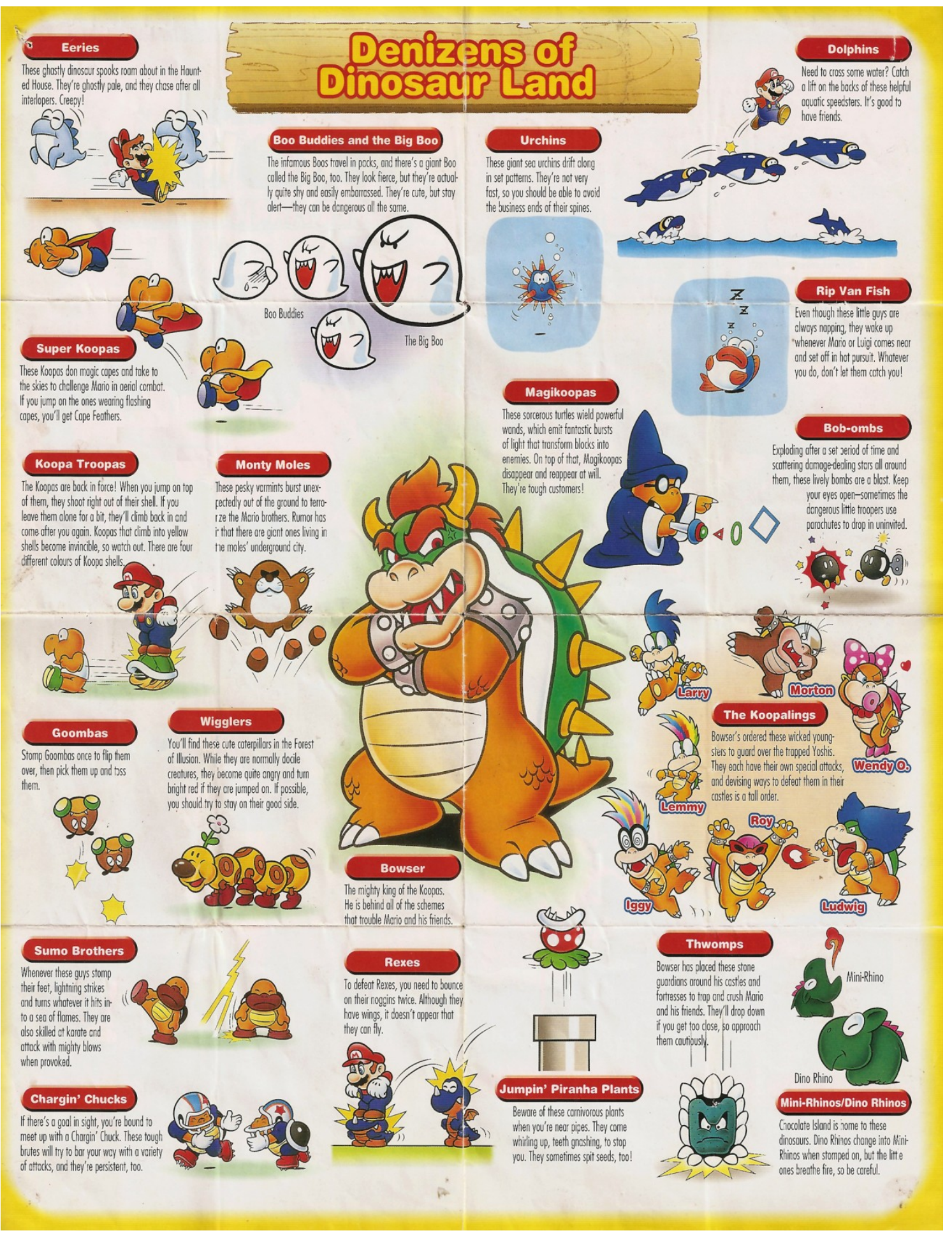

Fonte: Super Mario Wiki. Disponível em: https://www.mariowiki.com/, acesso em 18/01/2019. 